\title{
AKTIVITAS ANTI BAKTERI BIJI DAN KULIT BUAH ALPUKAT (Persea Americana Mill.) TERHADAP Aerobacter aerogenes DAN Proteus mirabilis
}

\author{
A. Yachya ${ }^{1)}$ dan Sulistyowati ${ }^{2}$

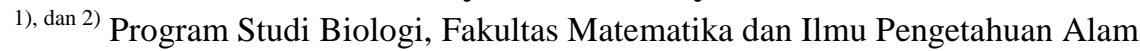 \\ Universitas PGRI Adi Buana (UNIPA) Surabaya \\ Email : ayachya@gmail.com
}

\begin{abstract}
Abstrak
Penelitian ini bertujuan untuk mengetahui pengaruh umur dan konsentrasi ekstrak air biji dan kulit buah alpukat terhadap pertumbuhan Aerobacter aerogenes dan Proteus mirabilis. Biji dan kulit buah alpukat yang digunakan berumur 4, 5 dan 6 bulan dengan variasi konsentrasi ekstrak 20, 40, 60, dan 80\% (v/v). Hasil uji menunjukkan ekstrak air biji buah alpukat konsentrasi $80 \%$ pada semua umur biji mampu menghambat total pertumbuhan A.aerogenes. Pada konsentrasi $60 \%$ umur biji 5 dan 6 bulan mampu menurunkan pertumbuhan A.aerogenes dari $10^{8}$ menjadi $10^{6} \mathrm{CFU} / \mathrm{mL}$. Hasil uji pada P. mirabilis menunjukkan konsentrasi ekstrak $80 \%$ pada semua umur biji tidak mampu menghambat total pertumbuhan P. mirabilis. Ekstrak biji umur 4 bulan pada semua konsentrasi efektif menghambat P. mirabilis dibandingkan ekstrak biji umur 5 dan 6 bulan. Hasil uji aktivitas antibakteri ekstrak air kulit buah menunjukkan A.aerogenes dan P. mirabilis relatif resisten. Pada perlakuan semua umur kulit dengan berbagai konsentrasi rata-rata mampu menurunkan populasi kedua jenis bakteri uji dari $10^{8} \mathrm{CFU} / \mathrm{mL}$ menjadi $10^{7} \mathrm{CFU} / \mathrm{mL}$. Berdasarkan hasil uji, penggunaan kombinasi ekstrak air biji buah alpukat umur 4 dan 6 bulan dengan konsensentrasi $80 \%(\mathrm{v} / \mathrm{v})$ direkomendasikan sebagai bahan obat tradisional untuk menyembuhkan penyakit yang disebabkan A. aerogenes dan P. mirabilis.
\end{abstract}

Kata kunci: Aerobacter aerogenes, Biji dan Kulit Alpukat, Proteus mirabilis.

\begin{abstract}
This research aims to determine the effect of age and concentration of water extract of avocado seeds and peels on Aerobacter aerogenes and Proteus mirabilis growth. Seeds and peels are collected from fruit at age 4, 5 and 6 months old. The variation of extract concentrations are tested 20, 40, 60, and $80 \%(\mathrm{v} / \mathrm{v})$. The results showed that the water extract of various age seeds in concentration $80 \%$ totally inhibited A. aerogenes growth. The extract of seeds at age 5 and 6 months in concentration $60 \%$ were able to decrease A.aerogenes populations from $10^{8}$ to $10^{6}$ $C F U / m L$. The differing results were showed on antibacterial test of $P$. mirabilis. The seed extract of various age in concentration $80 \%$ did not totally inhibit P. mirabilis growth. The seed extract at age 4 months old on various concentrations was effective to inhibit $P$. mirabilis growth than seed extract at age 5 and 6 months old. The results of antibacterial test of water extracts from avocado peels on $P$. mirabilis and A.aerogenes showed resistance. All treatments with various concentrations of pell extract were able to decrease the population of both bacterial test from $10^{8}$ $\mathrm{CFU} / \mathrm{mL}$ to $10^{7} \mathrm{CFU} / \mathrm{mL}$. Based on the results, combination of water extracts between avocado seed at age 4 and 6 months old in concentration $80 \%(\mathrm{v} / \mathrm{v})$ is recommended to cure diseases by $A$. aerogenes and $P$. mirabilis.
\end{abstract}

Keywords : Aerobacter aerogenes, Seed and Peel Avocado, Proteus mirabilis. 


\section{PENDAHULUAN}

Alpukat merupakan buah yang banyak digemari masyarakat karena rasanya yang lezat dan mengandung berbagai macam nutrisi. Selain dikonsumsi sebagai makanan, alpukat juga digunakan sebagai campuran produk kosmetika. Akan tetapi pemanfaatan buah alpukat yang begitu banyak ini tidak diiringi dengan pemanfaatan biji dan kulitnya. Selama ini kulit dan biji buah alpukat cenderung dibuang begitu saja (Leite et al., 2009).

$\begin{array}{rlr}\text { Biji } & \text { buah alpukat secara } & \text { tradisional } \\ \text { banyak } & \text { digunakan sebagai } & \text { sumber }\end{array}$ fitoterapeutik untuk mengatasi infeksi parasit dan mikosis. Diketahui biji alpukat mengandung senyawa fitosterol, triterpen, asam lemak, asam furanoik, dimer flavonol, proantosianidin, dan asam absisat. Beberapa senyawa tersebut telah terbukti memiliki aktivitas antifungi dan efek larvasidal (Leite $e t$ a.l, 2009). Berdasarkan kandungan pada biji alpukat, diduga kulit buah memiliki kandungan yang relatif sama karena keduanya dalam satu bagian buah yang sama. Selain itu, diduga tingkat kematangan atau umur buah alpukat termasuk biji dan kulit buah yang merupakan bagian dari buah akan mempengaruhi kandungan metabolit sekunder di dalam biji dan kulit buah alpukat. Buah alpukat yang masak diduga kandungan metabolit sekunder pada biji dan kulit buahnya lebih besar dibandingkan pada buah alpukat yang masih muda.

Pada umumnya pertumbuhan sel dengan produksi metabolit sekunder mempunyai hubungan terbalik. Fenomena ini terjadi di tanaman dan di kultur sel. Produk metabolit sekunder diproduksi pada akhir fase stasioner ketika kandungan nutrisi medium mulai menurun. Fase puncak dan akhir perkembangan buah alpukat ditandai dengan masaknya buah alpukat, sehingga diharapkan kandungan metabolit sekunder di biji dan kulit buahnya maksimal. Pengaruh ekstrak air biji dan kulit buah alpukat dengan umur yang berbeda terhadap pertumbuhan A. aerogenes dan $P$. mirabilis belum diungkap. Oleh karena itu perlu dilakukan penelitian secara in vitro untuk mengetahui aktifitas antibakteri ekstrak air biji dan kulit buah alpukat pada umur yang berbeda terhadap P.mirabilis dan A.aerogenes. Hasil penelitian ini diharapkan dapat menjadi acuan masyarakat bilamana menggunakan biji dan kulit buah alpukat untuk pengobatan penyakit yang disebabkan $A$. Aerogenes dan $P$. Mirabilis.

\section{METODE}

\section{Koleksi bahan tanaman}

Buah alpukat yang berumur 4,5, dan 6 bulan diperoleh dari Kecamatan Pacet Kabupaten Mojosari Jawa Timur pada bulan Januari 2015.

\section{Pembuatan simplisia}

Biji dan kulit buah alpukat segar dipisahkan dari daging buah dan dicuci bersih. Keduanya diiris tipis dan dikering-anginkan selama satu minggu. Irisan biji dan kulit dihaluskan dengan mesin grinding dengan 20 mesh hingga diperoleh bentuk serbuk.

\section{Pembuatan ekstrak air biji dan kulit buah alpukat}

Pembuatan ekstrak dilakukan dengan metode infundasi. Dua puluh lima (25) gram serbuk biji atau kulit buah alpukat dimasukkan ke dalam panci infusa yang berisi $100 \mathrm{~mL}$ akuades. Ekstraksi dilakukan dengan pemanasan pada suhu $90{ }^{\circ} \mathrm{C}$ selama 30 menit. Selanjutnya dilakukan penyaringan menggunakan kertas saring Whatman nomor 1. Bilamana volume filtrat yang diperoleh kurang dari $100 \mathrm{~mL}$, maka ditambahkan akuades steril sampai volume filtrate menjadi $100 \mathrm{~mL}$. Filtrat yang diperoleh pada tahap ini dianggap sebagai filtrate induk dengan konsentrasi $100 \% \quad(\mathrm{v} / \mathrm{v})$ yang belum mengalami pengenceran. Filtrat induk disimpan pada suhu $18{ }^{0} \mathrm{C}$ dalam lemari pendingin.

\section{Persiapan bakteri uji}

Dua (2) jenis bakteri uji, yaitu Aerobacter aerogenes dan Proteus mirabilis diperoleh dari Balai Besar Laboratorium Kesehatan Surabaya. Bakteri uji dipelihara di media agar MacConcey (Merck) pada suhu kamar. Satu (1) loop koloni masing-masing jenis bakteri uji yang berusia 24 jam diinokulasikan secara terpisah pada test tube yang berisi $5 \mathrm{~mL}$ media nutrient broth (Merck). Kultur diinkubasi pada suhu kamar selama 16 jam. Pada akhir waktu inkubasi dilakukan pengujian turbiditas kultur secara spektrofotometrik pada panjang gelombang 
$625 \mathrm{~nm}$. Kultur diset turbiditasnya hingga diperoleh suspensi bakteri uji dengan nilai turbiditas sama dengan standar McFarland 0.5 atau memiliki kisaran populasi sel $1,5 \times 10^{8}$ $\mathrm{CFU} / \mathrm{mL}$. Standar McFarland 0.5 dibuat dengan mencampurkan $0.5 \mathrm{~mL} \mathrm{BaCl}_{2}$ (Merck) $1 \%$ (b/v) ke dalam $99 \mathrm{~mL}$ larutan $\mathrm{H}_{2} \mathrm{SO}_{4}$ (Merck) $1 \%$ (v/v) (Cavalieri et al., 2005). Selanjutnya pada masing-masing suspensi bakteri uji dilakukan pengenceran sampai 100 kali menggunakan larutan phospat buffer saline (PBS) untuk digunakan sebagai inokulum pada tahap uji aktivitas antibakteri.

\section{Metode uji aktivitas antibakteri}

Uji aktivitas antibakteri dilakukan dengan metode kontak. Pada tahap ini masing-masing filtrate induk biji dan kulit buah alpukat dari masing-masing kelompok umur yang berbeda (4, 5 dan 6 bulan) diencerkan. Pengenceran dilakukan dengan menambahkan nutrient broth dan suspensi bakteri uji (turbiditas sesuai standar McFarland 0.5) untuk memperoleh filtrate uji dengan konsentrasi 20, 40, 60, dan $80 \%$ (v/v). Tata cara pengenceran adalah sebagai berikut :

a. filtrat uji $20 \%(\mathrm{v} / \mathrm{v})$ terbuat dari campuran $1 \mathrm{~mL}$ suspensi bakteri $+7 \mathrm{~mL}$ nutrient broth steril $+2 \mathrm{~mL}$ filtrat $100 \%$ (v/v).

b. Filtrat uji $40 \%(\mathrm{v} / \mathrm{v})$ terbuat dari campuran $1 \mathrm{~mL}$ suspensi bakteri $+5 \mathrm{~mL}$ nutrient broth steril $+4 \mathrm{~mL}$ filtrat $100 \%$ (v/v)

c. filtrat uji $60 \%$ (v/v) terbuat dari campuran 1 $\mathrm{mL}$ suspensi bakteri $+3 \mathrm{~mL}$ nutrient broth steril $+6 \mathrm{~mL}$ filtrat $100 \%(\mathrm{v} / \mathrm{v})$.

d. filtrat uji $80 \%(\mathrm{v} / \mathrm{v})$ terbuat dari campuran 1 $\mathrm{mL}$ suspensi bakteri $+1 \mathrm{~mL}$ nutrient broth steril $+8 \mathrm{~mL}$ filtrat $100 \%(\mathrm{v} / \mathrm{v})$.
Masing-masing filtrate uji dengan suspensi bakteri uji yang berbeda diinkubasi selama 16 jam. Pada akhir waktu inkubasi dilakukan penghitungan total populasi masingmasing bakteri uji menggunakan metode hitungan cawan (plate count). Media kultivasi yang digunakan adalah MacConcey agar dengan metode isolasi cawan sebar menggunakan batang kaca penyebar. Semua cawan diinkubasi pada suhu $37^{\circ} \mathrm{C}$ selama 24 jam dengan posisi terbalik. Metode hitungan cawan didasarkan pada anggapan bahwa setiap sel yang dapat hidup akan berkembang menjadi satu koloni (Hadioetomo, 1990), sehingga jumlah koloni bakteri uji merupakan representatif jumlah sel yang hidup dan mampu bertahan sampai akhir waktu inkubasi pada masing-masing sampel (filtrate uji).

\section{Analisis data \\ Data total populasi bakteri hasil pencawanan masing-masing filtrate uji biji dan kulit buah alpukat dari masing-masing kelompok umur yang berbeda dianalisis secara statistik menggunakan uji anava dua arah dengan selang kepercayaan 5\%. Apabila ada perbedaan maka dilanjutkan dengan uji Kruskal Wallis. Uji statistik dilakukan dengan bantuan software IBM SPSS Statistics 20.}

\section{HASIL DAN PEMBAHASAN}

Pada penelitian ini diperoleh data aktivitas antibakteri ekstrak biji dan kulit buah alpukat terhadap bakteri Aerobacter aerogenes dan Proteus mirabilis.

\section{Hasil uji aktivitas antibakteri ekstrak biji}

Filtrat induk masing-masing serbuk biji buah alpukat dari 3 kelompok umur yang berbeda (4, 5 dan 6 bulan) dengan konsentrasi 20, 40, 60 dan $80 \%$ (v/v) diuji aktivitas antibakterinya terhadap $A$. aerogenes dan $P$. Mirabilis (Tabel 1 dan 2).

Tabel 1. Total populasi Aerobacter aerogenes hasil uji aktivitas antibakteri masing-masing filtrate uji biji buah alpukat pada umur biji dan konsentrasi filtrate uji yang berbeda.

\begin{tabular}{ccc}
\hline $\begin{array}{c}\text { Umur Biji } \\
\text { (bulan) }\end{array}$ & $\begin{array}{c}\text { Konsentrasi filtrate uji } \\
(\% \text { v/v })\end{array}$ & Rerata Jumlah koloni (CFU/mL) \\
\hline \multirow{3}{*}{$4^{\mathrm{b}}$} & 20 & $1,00.10^{8 \mathrm{c}}$ \\
& 40 & $1,12.10^{7 \mathrm{~b}}$ \\
& 80 & $6,02.10^{6 \mathrm{a}}$ \\
& 80 & 0
\end{tabular}



Terhadaap Aerobacter Aerogenes dan Proteus Mirabilis

\begin{tabular}{lcc}
\hline & 20 & $1,00.10^{8 \mathrm{c}}$ \\
$5^{\mathrm{a}}$ & 40 & $1,07.10^{7 \mathrm{~b}}$ \\
& 60 & $5,01.10^{6 \mathrm{a}}$ \\
& 80 & $0 *$ \\
& 20 & $1,00.10^{8 \mathrm{c}}$ \\
$6^{\mathrm{a}}$ & 40 & $8.55 \cdot 10^{6 \mathrm{~b}}$ \\
& 60 & $3.92 .10^{6 \mathrm{a}}$ \\
Kontrol* & 80 & $0 *$ \\
\hline
\end{tabular}

Keterangan : Nilai rerata yang diikuti dengan superskrip (huruf) yang berbeda, berbeda nyata ( $\alpha>$ $0,05) ;(*)$ rerata tidak diuji secara statistik.

Hasil analisis varian Rerata jumlah koloni A. aerogenes (Tabel 1) menunjukkan perlakuan umur biji dan konsentrasi filtrate uji biji buah alpukat berpengaruh terhadap pertumbuhan $A$. aerogenes. Pada semua tingkat umur biji $(4,5$ dan 6 bulan) menunjukkan semakin tinggi konsentrasi filtrate uji, maka semakin besar penurunan jumlah sel atau kematian A. aerogenes. Aktivitas antibakteri filtrate uji biji umur 4 bulan berbeda nyata dan lebih rendah dari filtrate uji biji umur 5 dan 6 bulan. Sedangkan filtrate uji biji umur 5 bulan tidak berbeda nyata dengan filtrate uji biji umur 6 bulan. Konsentrasi minimal filtrate uji biji yang berpengaruh terhadap pertumbuhan $A$. aerogenes dan berbeda nyata dengan kontrol dicapai oleh filtrate uji konsentrasi $40 \%$ dari semua tingkatan umur biji. Konsentrasi ini merupakan konsentrasi hambat minimal ekstrak air biji buah alpukat terhadap $A$. aerogenes. Sedangkan konsentrasi bunuh minimal dicapai oleh filtrate uji konsentrasi $80 \%$ semua dari semua tingkatan umur biji.

Tabel 2. Total populasi Proteus mirabilis hasil uji aktivitas antibakteri masing-masing filtrate uji biji biji buah alpukat pada umur biji dan konsentrasi filtrate uji yang berbeda.

\begin{tabular}{ccc}
\hline $\begin{array}{c}\text { Umur Biji } \\
\text { (bulan) }\end{array}$ & $\begin{array}{c}\text { Konsentrasi filtrate uji } \\
(\% \text { v/v })\end{array}$ & $\begin{array}{c}\text { Rerata Jumlah koloni } \\
(\text { CFU/mL) }\end{array}$ \\
\hline \multirow{3}{*}{$4^{\mathrm{a}}$} & 20 & $1,51.10^{6 \mathrm{bc}}$ \\
& 40 & $8,50.10^{4 \mathrm{abc}}$ \\
& 60 & $6,00.10^{4 \mathrm{ab}}$ \\
$5^{\mathrm{b}}$ & 80 & $2,50.10^{3 \mathrm{a}}$ \\
& 20 & $1,00.10^{8 \mathrm{bc}}$ \\
& 40 & $1,65.10^{7 \mathrm{abc}}$ \\
$6^{\mathrm{b}}$ & 60 & $4,52.10^{6 \mathrm{ab}}$ \\
& 80 & $5,05.10^{5 \mathrm{a}}$ \\
& 20 & $1,00.10^{8 \mathrm{bc}}$ \\
& 60 & $6,96.10^{7 \mathrm{abc}}$ \\
& 80 & $1,46.10^{7 \mathrm{ab}}$ \\
& Kontrol $^{*}$ & $7,92.10^{6 \mathrm{a}}$ \\
\hline
\end{tabular}

Keterangan : Nilai rerata yang diikuti dengan superskrip (huruf) sama, tidak berbeda nyata $(\alpha<$ 0,05 ). Sedangkan nilai rerata yang diikuti dengan superskrip (huruf) yang berbeda, berbeda nyata $(\alpha>0,05)$.

Hasil analisis varian rerata jumlah koloni P. mirabilis (Tabel 2) menunjukkan perlakuan umur biji dan konsentrasi filtrate uji biji buah alpukat berpengaruh terhadap pertumbuhan $P$. mirabilis. Pada semua tingkat umur biji memberikan respon yang seragam, yaitu semakin tinggi konsentrasi filtrate uji, maka semakin besar penurunan jumlah sel atau kematian $P$. mirabilis. Bila ditinjau dari umur biji, maka penurunan jumlah sel terbesar dicapai oleh filtrate uji biji buah alpukat umur 4 bulan yang berbeda nyata dengan filtrate uji 
biji buah alpukat umur 5 dan 6 bulan. Sedangkan bila ditinjau dari konsentrasi larutan filtrate uji, maka penurunan terbesar dicapai oleh filtrate uji konsentrasi $80 \%$. Konsentrasi terbaik dari semua tingkatan umur biji dalam menurunkan jumlah sel $P$. mirabilis dicapai pada filtrate uji biji buah alpukat umur 4 bulan konsentrasi $80 \%$. Konsentrasi hambat minimal filtrate uji biji buah alpukat terhadap $P$. mirabilis dicapai pada semua tingkatan umur biji dengan konsentrasi filtrate uji $60 \%$. Sedangkan nilai konsentrasi bunuh minimal sampai konsentrasi filtrate uji $80 \%$ pada semua tingkatan umur biji belum tercapai

\section{Hasil uji aktivitas antibakteri ekstrak kulit}

Filtrat induk masing-masing serbuk kulit buah alpukat dari 3 kelompok umur yang berbeda (4, 5 dan 6 bulan) dengan konsentrasi 20, 40, 60 dan $80 \%$ (v/v) diuji aktivitas antibakterinya terhadap $A$. aerogenes dan $P$. mirabilis (Tabel 3 dan 4).

Tabel 3. Total populasi Aerobacter aerogenes hasil uji aktivitas antibakteri masing-masing filtrate uji kulit buah alpukat pada umur kulit dan konsentrasi filtrate uji yang berbeda.

\begin{tabular}{|c|c|c|}
\hline $\begin{array}{c}\text { Umur kulit } \\
\text { (bulan) }\end{array}$ & $\begin{array}{c}\text { Konsentrasi filtrate uji } \\
(\% \mathrm{v} / \mathrm{v})\end{array}$ & Rerata Jumlah koloni (CFU/mL) \\
\hline \multirow{4}{*}{$4^{\mathrm{a}}$} & 20 & $1,63 \cdot 10^{7 \mathrm{~d}}$ \\
\hline & 40 & $1,29.10^{7 \mathrm{c}}$ \\
\hline & 60 & $1,13 \cdot 10^{7 b}$ \\
\hline & 80 & $9,28 \cdot 10^{6 \mathrm{a}}$ \\
\hline \multirow{4}{*}{$5^{\mathrm{a}}$} & 20 & $1,70 \cdot 10^{7 \mathrm{~d}}$ \\
\hline & 40 & $1,48 \cdot 10^{7 \mathrm{c}}$ \\
\hline & 60 & $1,23 \cdot 10^{7 b}$ \\
\hline & 80 & $1,10 \cdot 10^{7 \mathrm{a}}$ \\
\hline \multirow{4}{*}{$6^{\mathrm{b}}$} & 20 & $1,00 \cdot 10^{8 *}$ \\
\hline & 40 & $1,00 \cdot 10^{8 *}$ \\
\hline & 60 & $1,00 \cdot 10^{8 *}$ \\
\hline & 80 & $1,00 \cdot 10^{8 *}$ \\
\hline Kontrol* & 0 & $1,00.10^{8 *}$ \\
\hline
\end{tabular}

Keterangan : Nilai rerata yang diikuti dengan superskrip (huruf) yang berbeda, berbeda nyata ( $\alpha>$ $0,05) ;(*)$ rerata tidak diuji secara statistik. $) ;(*)$ rerata tidak diuji secara statistik.

Hasil analisis varian rerata jumlah koloni A. aerogenes (Tabel 3) menunjukkan perlakuan umur kulit dan konsentrasi filtrate uji kulit buah alpukat berpengaruh terhadap pertumbuhan $A$. aerogenes. Pada tingkat umur kulit 4 dan 5 bulan menunjukkan semakin tinggi konsentrasi filtrate uji, maka semakin besar penurunan jumlah sel atau kematian $A$. aerogenes. Akan tetapi penurunan jumlah sel pada masing-masing filtrate uji relatif kecil. Aktivitas antibakteri filtrate uji kulit umur 4 bulan tidak berbeda nyata dengan filtrate uji kulit umur 5 bulan dan keduanya berbeda nyata dan lebih tinggi dari filtrate uji kulit umur 6 bulan. Semua konsentrasi filtrate uji kulit umur 6 bulan tidak berpengaruh terhadap pertumbuhan $A$. aerogenes yang ditunjukkan dengan rerata jumlah koloni $A$. aerogenes yang sama dengan control. Konsentrasi hambat minimal filtrate uji kulit yang berpengaruh terhadap pertumbuhan $A$. aerogenes dan berbeda nyata dengan kontrol dicapai oleh filtrate uji konsentrasi $20 \%$ dengan tingkatan umur kulit 4 dan 5 bulan. Sedangkan konsentrasi bunuh minimal sampai konsentrasi filtrate uji $80 \%$ pada semua tingkatan umur kulit belum tercapai. 
Tabel 4. Total populasi Proteus mirabilis hasil uji aktivitas antibakteri masing-masing filtrate uji kulit buah alpukat pada umur kulit dan konsentrasi filtrate uji yang berbeda.

\begin{tabular}{ccc}
\hline $\begin{array}{c}\text { Umur kulit } \\
\text { (bulan) }\end{array}$ & $\begin{array}{c}\text { Konsentrasi filtrate uji } \\
(\% \text { v/v })\end{array}$ & Rerata Jumlah koloni $(\mathbf{C F U} / \mathbf{m L})$ \\
\hline \multirow{3}{*}{$4^{\mathrm{a}}$} & 20 & $1,82.10^{7 \mathrm{~d}}$ \\
& 40 & $1,61.10^{7 \mathrm{c}}$ \\
& 60 & $1,50.10^{7 \mathrm{~b}}$ \\
& 80 & $1,04.10^{7 \mathrm{a}}$ \\
$5^{\mathrm{b}}$ & 20 & $1,87.10^{7 \mathrm{~d}}$ \\
& 40 & $1,72.10^{7 \mathrm{c}}$ \\
& 60 & $1,59.10^{7 \mathrm{~b}}$ \\
$6^{\mathrm{b}}$ & 80 & $1,21.10^{7 \mathrm{a}}$ \\
& 20 & $1,88.10^{7 \mathrm{~d}}$ \\
& 40 & $1,76.10^{7 \mathrm{c}}$ \\
Kontrol* $^{*}$ & 60 & $1,61.10^{7 \mathrm{~b}}$ \\
& 80 & $1,27.10^{7 \mathrm{a}}$ \\
& 0 & $1,00.10^{8 *}$ \\
\hline
\end{tabular}

Keterangan : Nilai rerata yang diikuti dengan superskrip (huruf) yang berbeda, berbeda nyata ( $\alpha>$ $0,05) ;(*)$ rerata tidak diuji secara statistik.

Hasil analisis varian rerata jumlah koloni P. mirabilis (Tabel 4) menunjukkan perlakuan umur kulit dan konsentrasi filtrate uji kulit buah alpukat berpengaruh terhadap pertumbuhan $P$. mirabilis. Pada semua tingkat umur kulit memberikan respon yang seragam, yaitu semakin tinggi konsentrasi filtrate uji, maka semakin besar penurunan jumlah sel $P$. mirabilis. Penurunan jumlah sel pada masingmasing filtrate uji relatif kecil. Rerata jumlah sel $P$. mirabilis berkurang dari $1.10^{8}$ $\mathrm{CFU} / \mathrm{mL}$ kontrol) menjadi 1,04. $10^{7} \mathrm{CFU} / \mathrm{mL}$. Konsentrasi hambat minimal larutan filtrate uji kulit buah alpukat terhadap $P$. mirabilis dicapai pada semua tingkatan umur kulit dengan konsentrasi filtrate uji $20 \%$. Sedangkan konsentrasi bunuh minimal sampai konsentrasi filtrate uji $80 \%$ pada semua tingkatan umur kulit belum tercapai.

Hasil uji aktivitas antibakteri metode kontak ekstrak air biji dan kulit buah alpukat pada semua tingkatan umur $(4,5$ dan 6 bulan) dengan konsentrasi filtrate uji $(20,40,60$, dan $80 \%(\mathrm{v} / \mathrm{v}))$ memberikan informasi tentang efektifitas bahan aktif yang terkandung di dalam biji dan kulit buah alpukat. Rerata jumlah koloni hasil pencawanan masingmasing filtrate uji (Tabel 1-6) menunjukkan bahwa umur biji dan kulit dengan berbagai variasi konsentrasi berpengaruh signifikan terhadap pertumbuhan bakteri A. aerogenes dan $P$. mirabilis. Semakin tinggi konsentrasi filtrate uji, maka semakin besar jumlah sel kedua bakteri uji yang mengalami kematian. Tren penurunan rerata jumlah koloni $A$. aerogenes berbeda dengan $P$. mirabilis. Perbedaan ini mengindikasikan berbedanya kandungan zat aktif antara biji dan kulit buah alpukat.

Hasil uji beda menunjukkan larutan ekstrak biji buah alpukat umur 5 dan 6 bulan rata-rata memiliki kemampuan penghambatan lebih baik terhadap $A$. aerogenes daripada ekstrak biji umur 4 bulan (Tabel 1). Kemampuan penghambatan antara ekstrak biji buah alpukat umur 5 dan 6 tidak berbeda nyata. Hasil ini menunjukkan kandungan zat aktif anti $A$. aerogenes terakumulasi seiring dengan bertambahnya umur biji buah alpukat. Meskipun demikian, pada perlakuan semua umur biji dengan konsentrasi filtrate uji $80 \%$ $(\mathrm{v} / \mathrm{v})$ mampu menghambat total pertumbuhan A. aerogenes.

Kemampuan penghambatan ekstrak biji alpukat pada berbagai umur biji dan konsentrasi filtrate uji terhadap $P$. mirabilis hasilnya berkebalikan dengan $A$. aerogenes (Tabel 2). Larutan ekstrak biji umur 4 bulan pada semua konsentrasi filtrate uji efektif menghambat $P$. mirabilis dibandingkan larutan ekstrak biji umur 5 dan 6 bulan. Pada perlakuan semua umur biji dengan konsentrasi filtrate uji $80 \quad \% \quad(\mathrm{v} / \mathrm{v})$ tidak mampu menghambat total pertumbuhan $P$. mirabilis. 
Hasil ini mengindikasikan kandungan tertinggi dari zat aktif anti $P$. mirabilis terdapat pada biji yang muda dan kandungannya berkurang seiring dengan bertambahnya umur biji buah alpukat

Hasil studi fitokimia pada biji alpukat telah mengidentifikasi berbagai senyawa metabolit sekunder, yaitu alkaloid, phitosterol, triterpen, asam furanoik, flavonol dimer, proanthosianidin, tannin, asam stearik, asam absisat, $\beta$ sitosterol, asam palmitik, asam palmitik, asam palmitoleat, asam oleat dan asam linoleat (Leite at al., 2009). Beberapa senyawa tersebut diketahui bersifat antifungi (Alcerito et al., 2002) dan larvasidal (Morais et al., 2007). Ovesna et al. (2004) melaporkan $\beta$ sitosterol mempunyai aktivitas antiinflamasi, anti-mikroba, anti-bakteri and antifungi.

Hasil uji aktivitas antibakteri metode kontak ekstrak kulit buah alpukat pada semua umur biji dan konsentrasi filtrate uji terhadap $A$. aerogenes dan $P$. mirabilis ditunjukkan pada Tabel 3 dan 4. Hasil uji menunjukkan kedua jenis bakteri uji relatif resisten. Pada perlakuan semua umur kulit dengan berbagai konsentrasi filtrate uji rata-rata mampu menurunkan populasi kedua jenis bakteri dari $10^{8} \mathrm{CFU} / \mathrm{mL}$ menjadi $10^{7} \mathrm{CFU} / \mathrm{mL}$. Penurunan ini relatif kecil bila dibandingkan dengan penurunan yang disebabkan oleh ekstrak biji. Hal ini mengindikasikan berbedanya jenis dan konsentrasi zat aktif anti bakteri yang terkandung diantara kulit dan biji buah alpukat. Menurut Kim et al., (2001), metabolit sekunder hanya terakumulasi di bagian tertentu dari tanaman, misalnya lawsone dan artemisin yang secara normal hanya terakumulasi di bagian aerial tanaman (Bakkali et al., 1997 dan Wallaart et al., 1999). Susanti et al., (2008) telah membuktikan kandungan saponin kolesom (Thalinum triangulare) hanya terkandung di bagian umbinya. Pada bagian daun dan batangnya mengandung metabolit sekunder lainnya seperti alkaloid, steroid dan flavonoid. Kajian fitokimia kulit buah alpukat sampai saat ini belum banyak diungkap. Adikaram et al. (1993) berhasil mengidentifikasi senyawa antifungi dari kulit buah alpukat yang belum masak, antara lain 1,2,4-trihidroksiheptadek16-ana; 1,2,4- trihidroksiheptadek-16-ana dan 1-asetoksi-2,4-dihidroksiheptadek-16-ana yang konsentrasinya menurun sampai level nontoksik seiring dengan masaknya buah. Selain itu, kulit biji alpukat dapat digunakan untuk mengobati penyakit cacing (Orwa et al., 2009).

Kuatnya aktivitas antibakteri biji alpukat yang berumur 6 bulan dibandingkan dengan biji yang berumur $4-5$ bulan disebabkan keberadaan zat aktif, yaitu metabolit sekunder yang terkandung di dalamnya. Menurut Manuhara (2014) produksi metabolit sekunder berjalan lambat pada fase pertumbuhan tanaman, bahkan seringkali belum dimulai, tetapi pada fase pertumbuhan berakhir maka produksi metabolit sekunder dimulai. Buah alpukat yang berumur 6 bulan memasuki fase akhir perkembangan buah, sehingga bila dianalogikan dengan perkembangan sel, maka buah alpukat berada pada fase stasioner dimana sintesis metabolit sekunder sedang berlangsung dan mengalami akumulasi. Oleh karena itu pada biji umur 6 bulan diindikasikan kandungan metabolit sekundernya lebih tinggi dibandingkan biji umur kurang dari 6 bulan. Berdasarkan hasil uji, penggunaan kombinasi ekstrak biji buah alpukat umur 4 dan 6 bulan dengan konsensentrasi $80 \%$ (v/v) direkomendasikan sebagai bahan obat tradisional untuk menyembuhkan penyakit yang disebabkan $A$. aerogenes dan $P$. mirabilis. Akan tetapi penggunaanya secara komersial masih memerlukan uji toksiksitas, sebab buah alpukat yang masih mudah bersifat racun (Orwa et al., 2009).

\section{KESIMPULAN}

Berdasarkan hasil uji, penggunaan kombinasi ekstrak biji buah alpukat umur 4 dan 6 bulan dengan konsensentrasi 80\% (v/v) direkomendasikan sebagai bahan obat tradisional untuk menyembuhkan penyakit yang disebabkan $A$. aerogenes dan $P$. mirabilis.

\section{Ucapan Terima Kasih}

Kami mengucapkan terima kasih kepada Universitas PGRI Adi Buana sebagai penyandang dana penelitian. 
A.Yachya \& Sulistyowati : Aktivitas Anti Bakteri Biji dan Kulit Buah Alpukat (Persea Americana Mill) Terhadaap Aerobacter Aerogenes dan Proteus Mirabilis

\section{DAFTAR PUSTAKA}

Alcerito T., Barbo F.E., Negri G., Santos D.Y.A.C., Meda C.I, Young M.C.M., Chávez D and Blatt C.T.T. 2002. Foliar Epicuticular Wax of Arrabidaea brachypoda: flavonoids and antifungal activity. Biochemical Systematics and Ecollogy. 30: 677-683.

Adikaram N.H.B., Egodawela N.A and Karunaratne A. 1993. Antifungal Compounds In The Avocado Fruit Peel And Their Relation To Anthracnose Development. ISHS Acta Horticulturae. 343.5.

Bakkali A. T., Jaziri M., Foriers A., Vander Heyden Y., Vanhaelen M and Homes J. 1997. Lawsone accumulation in normal and transformed cultures of Henna, Lawsonia inermis. Plant Cell Tiss. Organ Cult. 51:83-87.

Hadioetomo, S.S dan Razdan M.K., 1996., Plant Tissue Culture: Theory and Practice, a Revised Edition., Elsevier

Cavalieri, Stephen J et al. 2005. Manual of Antimicrobial Suscepbility Testing. American Society for Biology, America.

Hadioetomo, Ratna Siri. 1990. Mikrobiologi Dasar dalam Praktek. PT. Gramedia, Jakarta.

Kim Y.J., Wyslouzil B.E and Weathers P.J. 2001. Invited review: secondary metabolism of hairy root cultures in bioreactors. In Vitro Cell. Dev.Biol.-Plant. 38:1-10.

Leite, J.J.G., Brito, E.H.S., Cordeiro, R.A., Brilhante, R.S.N., Sidrim, J.J.C., Bertini, L.M., Morais, S.M.D., Rocha, M.F.G. 2009. Chemical Composition, Toxicity and Larvacidal and Antifungal Activities of Persea americana (Avocado) Seed Extract. Revista da Sociedadae Brasileira de Medicina Tropical. Vol. 2. No. 42. P. 110-113

Manuhara, Y.S.W. 2014. Kapita Selekta Kultur Jaringan Tanaman. Airlangga University Press, Surabaya.

Orwa C., Mutua A ., Kindt R ., Jamnadass R and Simons A. 2009. Agroforestree Database: a tree reference and selection guide Version 4.0 (http: //www.worldagroforestry.org/af/treedb/)

Susanti H., Arifin S dan Melati M. 2008. Produksi biomassa dan bahan bioaktif kolesom (Talinum triangulare (Jacq.Wild) dari berbagai asal bibit dan dosis pupuk kandang ayam. Buletin Agronomi. 36: 48-55.

Wallaart T.E., Pras N and Quax W.J. 1999. Isolation and identification of dihydroartemisinic acid hydroperoxide from Artemisia апnиа: a novel biosynthetic precursor of artemisinin. J. Nat. Prod. 62:1160-1162.

Ovesná Z., Vachálková A and Horváthová K. 2004. Taraxasterol and beta-sitosterol: New naturally compounds with chemoprotective effects. Neoplasma. 51: 407-414.

Morais S.M., Facundo V.A., Bertini L.M., Cavalcanti E.S.B., Anjos Júnior J.F., Ferreira S.A., Brito E.S and Souza Neto MA. 2007. Chemical Composition and Larvicidal Activity of Essential Oils from Piper Species. Biochemical Systematics and Ecollogy. 35: 670-675. 